\title{
TECHNIQUES TO UPGRADE INDIAN SOLAR POWER SECTOR BY ANALYSING THE TOP RANKING SOLAR POWER COUNTRIES
}

\author{
Shantanu Rawat ${ }^{1}$, Himanshi Rana ${ }^{2}$, Deepanvita Maurya ${ }^{3}$, Deepak Kumar ${ }^{4}$ \\ ${ }^{1}$ Department of Electrical, University of Petroleum \& Energy Studies, Dehradun, India \\ ${ }^{2}$ Department of Aerospace, University of Petroleum \& Energy Studies, Dehradun, India \\ ${ }^{3}$ Department of Mechanical, University of Petroleum \& Energy Studies, Dehradun, India \\ ${ }^{4}$ Assistant Professor, Department of Electrical, University of Petroleum \& Energy Studies, Dehradun, India
}

\begin{abstract}
As fossil fuels are depleting day by day it is the high time to switch to renewable energy. Many countries have already realized this fact and have started focusing on the renewable energies. The main focus of all countries is on solar power [1]. Though many countries have developed themselves in solar power generation since last one decades but India hasn't started yet. The major solar power producing countries are China, Germany and Japan and if we try to compare India with these countries we stand far apart in the queue. Though India has one of the best climatic conditions to support solar power generation. India is a sun-blessed country which has clear 300 days of sunshine, which is comparatively much more than the other countries [2]. The total power generated by India is 267,637.35 MW (till March 2015) and out of which we are generating only 5,050 MW through solar energy [3]. To satisfy the demand of power supply all over the country in future, we need to install more number of solar power plants such as to provide us maximum output as a result in much more advanced technique [4]. Hence it will also reduce the pollution and will lead to a healthy and sustainable environment.
\end{abstract}

Keywords- Fossil Fuels, Generation, Solar Power, Renewable Energies, Pollution

\section{INTRODUCTION}

According to the estimated data by the end of year 2015 , China has been declared as the world's enormous producer of electricity using solar energy followed by Germany \& Japan on 2nd \& 3rd positions respectively. Total installed photovoltaic capacity of China according to 2015 was $43,530 \mathrm{MW}$ ( $22.5 \%$ of total) out of which $15 \mathrm{MW}$ (34.6\% of $43,530 \mathrm{MW}$ ) were alone installed in the year 2015. Similarly, installed capacity of Germany in 2015 was $39,700 \mathrm{MW}$ $(20.6 \%$ of total) out of which $1,450 \mathrm{MW}(3.6 \%$ of 39,700MW). [5]

There are in total 1.5 million PV systems installed in Germany taking in account the systems installed on roof top, medium to large scale solar-power parks \& they entirely contributed to $35.2 \mathrm{TW}-\mathrm{h}$ in 2014 \& on other hand, China is the leading in field of solar water heating capacity, as, it has installed $92 \%$ vacuum tube solar water heaters.

On the other hand India had started solar in 2010 with installed capacity of 161 MW. Till 2016 we have achieved only about $6700 \mathrm{MW}$. This shows that we are moving with very slow pace. This paper consist the comparisons between the top ranking countries and their strategies which have help them to become leading solar power producing countries.

\section{CAPACITY}

It is quite interesting to know that China's and Germany's production is more than their consumed amount. Like if
China is taken into account, then according to 2013 its annual output is 5.398 trillion $\mathrm{KWh} \&$ use up is 5.380 trillion $\mathrm{KWh}$, which is produced with an installed capacity of $1247 \mathrm{GW}$. Whereas in 2011 the estimated data was 7.5 GW for Germany, produced 18TWh of electricity [6].

The compression of the current status of installed capacity between these countries with India is mentioned below in fig (a):

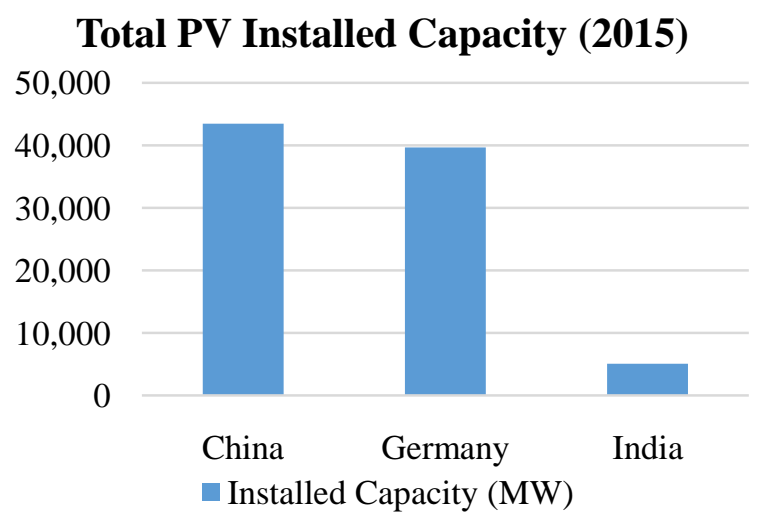

Fig (a)

Though India had Installed 2000 MW in 2015 which was more than Germany but we were behind four other countries. In 2015 China had installed 15,150 MW which was highest installed capacity among all countries. The largest PV power stations in China, Germany and India are listed below down in the table: 
Table 1

\begin{tabular}{|l|l|l|l|l|l|}
\hline PV Power Station Germany & $\begin{array}{l}\text { Capacity } \\
\text { in MW }\end{array}$ & $\begin{array}{l}\text { PV Power Station In } \\
\text { China }\end{array}$ & $\begin{array}{l}\text { Capacity } \\
\text { In MW }\end{array}$ & $\begin{array}{l}\text { PV Power Station In India } \\
\text { Capacity } \\
\text { in MW }\end{array}$ \\
\hline Meuro solar park & 166 & Chara-nka solar park & 221 & $\begin{array}{l}\text { Kamu-thi Solar Power } \\
\text { Project }\end{array}$ & 648 \\
\hline $\begin{array}{l}\text { Neuharde-nberg Airport solar } \\
\text { park }\end{array}$ & 145 & Golmund solar park & 200 & Chara-nka Solar Park & 221 \\
\hline Templi-n solar park & 128 & Xitieshan solar park & 100 & Wels-pun Solar MP project & 151 \\
\hline Eggebe-k Solar park & 83.6 & Gansu jaiyuguan solar park & 100 & Sakri solar plant & 125 \\
\hline
\end{tabular}

\section{CLIMATIC CONDITION}

The climatic factor of India is quite efficient for solar power generation as compared to Germany and Chine. India has 300 days of clear sunshine. About Five thousand Trillion KWh per year solar energy incidence on India. These countries don't have year-round sunshine. It's all about their management $\&$ proper utilization of the available resources. Like southern Germany have 1,600-1,800 hrs of annual sunlight, but if we talk about their sunniest region, say, Yuma \& Arizona they have 4,300 hrs of annual sunlight [7]. The Sonnenschiff and Solarsiedlung cities situated in Freiburg, are the solar cities of Germany [8]. On other hand if we talk about China, total 60 days of hot summer is available properly. If we compare China High temperature cities with India then it consist following cities:

Table 2

\begin{tabular}{|l|l|l|l|l|l|l|}
\hline S.No & Cities of India & Temperature $\left({ }^{\circ} \mathrm{C}\right)$ & Cities of China & Temperature $\left({ }^{\circ} \mathrm{C}\right)$ & Cities of Germany & Temperature $\left({ }^{\circ} \mathrm{C}\right)$ \\
\hline 1. & Nagpu-r & 48 & Wuhan & 34 & Karlsru-he & 40.2 \\
\hline 2. & Titlaga-rh & 47.6 & Chongqing & 34 & Gärmer-sdorf & 40.2 \\
\hline 3. & Wardh-a & 46.5 & Chongqing & 34 & Tempel-hof & 38.1 \\
\hline 4. & Samba-lpur & 46.4 & Fuzhou & 34 & Cottbus & 38.9 \\
\hline
\end{tabular}

These data shows those the country whose climatic condition is most suitable for solar power they are producing minimum solar power and the countries who have low temperature they are producing maximum solar power.

\section{TECHNOLOGY USED FOR SOLAR POWER GENERATION}

Now these are the basic details of these countries, these are the factors which are needed to be kept in consideration before moving ahead. We need to estimate this data and need to prepare their plan according to the conditions favouring their ideas \& goals only after proper availability of data we can establish their plan.

China: They do not use very advanced technology. In 2015, China becomes the leading producer of photovoltaic system. These are produced in very cheap price in China as compared to India. They produce $63 \%$ world's photovoltaic technology. It has 6 major solar companies having total value of $\$ 15$ billion. There are numerous plans under the golden sun scheme announced in 2009, such as the unwell technologies developed new thin film solar plant in Henan route using its own patent solar technology. The agreement of this 500MW of solar project in the desert was signed by LDK and along with the China pledged to adopt various new plans to use $15 \%$ of its energy from renewable resources within a decade [9].
Germany: Population of 12.5 million people in the state of Bavaria in Germany has three PV panels installed per residence. $90 \%$ solar panels out of total are installed on the home's rooftops [10].The main thing is grid management In spite of the fact that the solar power will make the supply unstable, they still have the most suitable electricity grids and apart from this they are focusing on develop 'smart' grids. Also the smart cities are designed by architect Rolf Dish, with last PV technology, which has the change of material that make them efficient \& they also have vacuum insulation for building's walls that provides favourable thermal performance. So these are the small initiatives taken by these countries to make use of solar energy.

Now this is clearly understood from above discussion that for production of large amount of solar power we need not to have very advanced technology. Only we need to have a proper planning and large number of solar panel installation.

\section{SUGGESTED TECHNIQUES FOR IMPROVEMENT SOLAR POWER IN INDIA}

To achieve the target of $40 \mathrm{MW}$ till the end of year 2022 we have to focus on our technology and have to create different laws. Some of the techniques are mentioned below

- Every newly constructed building in metro cities should contain solar panel on the rooftop.

- In each and every colony 50\% of solar street light installation should be compulsory. 
- For street Light we can install solar panel tracking which can detect sunlight and it will be more efficient and can be utilized for more period of time.

- Government should start giving subsidy for the consumers.

- Each colony must have solar tree for solar power generation within the colony.

\section{CONCLUSION}

By this paper we conclude that, if China \& Germany can became the world's solar energy leaders then India can also achieve it. It is easily possible by the support of public of India \& different policies run by government in the favour of this decision.

\section{REFERENCES}

[1] "Evolution of solar energy in India: A review", Sciencedirect.com, 2017. [Online]. Available: http://www.sciencedirect.com/science/article/pii/S1364 03211400570X

[2] "A review on solar energy use in industries", Sciencedirect.com, 2017. [Online]. Available: http://www.sciencedirect.com/science/article/pii/S1364 032110004533.

[3] "A review on solar energy use in industries", Sciencedirect.com, 2017. [Online]. Available: http://www.sciencedirect.com/science/article/pii/S1364 032110004533.

[4] "A review of the applications of nanofluids in solar energy", Sciencedirect.com, 2017. [Online].

[5] Available:

http://www.sciencedirect.com/science/article/pii/S0017 931012008034.

[6] "Renewable energy in India: Current status and future potentials", Sciencedirect.com, 2017.

[7] [Online].

Available: http://www.sciencedirect.com/science/article/pii/S1364 032110001140 .

[8] 6. "Renewable energy in India: Current status and future potentials", Sciencedirect.com, 2017.

[9] [Online]. Available: http://www.sciencedirect.com/science/article/pii/S1364 032110001140 .

[10] $2017 . \quad$ [Online]. Available: https://en.wikipedia.org/wiki/Solar_power_in_China

[11] https://en.wikipedia.org/wiki/Energy_policy_of_China.

[12] 8. Contributor, "How Germany Became a Solar Superpower", Triple Pundit: People, Planet, Profit, 2017.

[Online].

Available:http://www.triplepundit.com/2015/08/germa ny-became-solar-superpower/.

9. "International Monetary Fund", En.wikipedia.org, 2017. [Online]. Available:

[13] https://en.wikipedia.org/wiki/International_Monetary_F und.

[14] 10. Curry, "Even Environmentalists Are Beginning to Grumble about Germany's Solar Boom", Slate Magazine, 2017. [Online]. Available: http://www.slate.com/articles/health_and_science/alter native_energy/2013/03/solar_power_in_germany_how _a_cloudy_country_became_the_world_leader_in_sola r.html. 